\title{
"Songs of Malice and Spite"?: Wales, Prince Charles, and an Anti-Investiture Ballad of Dafydd Iwan
}

\section{CRAIG OWEN JONES}

In 1969, Charles Windsor, the heir apparent to the British throne, turned twenty-one, and on July 1, he was formally invested with the title of Prince of Wales, the honor usually bestowed on the eldest son of the ruling British monarch. The lavish investiture ceremony at Caernarfon Castle was, in fact, constitutionally devoid of meaning: Charles had been created Prince of Wales over a decade earlier, in 1958, and in any case, the role carried with it no official or constitutional duties. However, the ceremony was meant to have another, more immediate beneficial effect; as The Times put it, it was also intended as "a public relations and political sop to pacify the nationalist stirrings of Wales."1

It is a matter of public record that the investiture of Charles-Queen Elizabeth II's eldest son-with the title of Prince of Wales was the occasion of considerable controversy in Wales and among the Welsh, whose sense of nationhood had undergone a renaissance in the quarter century since the end of the Second World War. The growing sense of political powerlessness actuated by the failure of the "Parliament for Wales" campaign in the 1950s was exacerbated by the Tryweryn affair, in which the entire population of the Welsh-speaking village of Capel Celyn in rural north Wales were summarily evicted from their homes to make way for a reservoir completed in 1965 to provide water for the English industrial sector, in spite of unanimous opposition from Welsh Members of Parliament. ${ }^{2}$ Allied to this was a growing understanding that Wales's cultural heritage was in severe danger of being eroded by Anglo-American cultural influences, and more specifically, by the increasing influence of the English language and the concomitant weakening of the Welsh language, a member of the Celtic family of languages, which was still spoken by twenty-six percent (about 650,000) of the Welsh population in 1961. It was in the light of dramatist and intellectual Saunders Lewis's impassioned description of the plight of the Welsh language in his 1962 radio broadcast Tynged yr Iaith (The Fate of the Language) that Cymdeithas yr Iaith Gymraeg (the Welsh Language Society; hereafter WLS) was formed, a pressure group with the remit of campaigning for civil rights for Welsh speakers through nonviolent means. ${ }^{3}$

The nonviolent protests of the WLS for bilingual road signs, official forms, and other symbolic and practical advances that would enable Welsh speakers to use their language in all domains of everyday life, together with a sporadic but long-running bombing campaign by militant Welsh nationalists bent on gaining independence for Wales from the United Kingdom, provided a most volatile backdrop for Prince Charles's investiture. The weeks and months leading up to the event saw the organizing of anti-investiture rallies, some attracting thousands in attendance; the boycotting of the ceremony by Plaid Cymru (The

\footnotetext{
${ }^{1}$ Quoted in Martin Johnes, “A Prince, a King, and a Referendum: Rugby, Politics, and Nationhood in Wales, 1969-1979," Journal of British Studies 47, no. 1 (2008): 129.

${ }^{2}$ Gwyn A. Williams, When Was Wales?(London: Penguin, 1985), 291.

${ }^{3}$ John Davies, A History of Wales (London: Penguin, 1993), 644, 649-50. For a history of the WLS, see Dylan Phillips, Trwy ddulliau chwyldro . . ? : Hanes Cymdeithas yr Iaith Gymraeg 1962-1992(Llandysul: Gomer, 1998).
} 
Party of Wales), a left-of-center nationalist party whose first MP, Gwynfor Evans, had been elected to the House of Commons only three years previously, not to mention boycotts by other (non-political) national organizations; ${ }^{4}$ the spilling of much ink in the Welsh press over the merits (or otherwise) of gaining an Englishman as the nation's prince; and in the late spring and early summer, a stepping-up of the campaign of bombings primarily against Wales's industrial infrastructure by militants, which culminated in the accidental death of two Welshmen on the morning of the investiture itself, when the bomb they were carrying blew up prematurely. ${ }^{5}$

Celebrations in Caernarfon were heartfelt on July 1, but the day was fraught with tension, and the divisive feelings that the royal visit had occasioned were obvious. A quarter of a million people were expected to come to the town, but only around ninety thousand did so. Car parks specially built in the town to accommodate the expected influx of well-wishers were less than full, and of the twenty-thousand schoolchildren in Caernarfonshire expected to visit Caernarfon on the day, only two thousand attended. ${ }^{6}$ On the streets of the town along which the royal procession was to pass, there were gaps in the crowds-a fact that one royalist-leaning newspaper gamely attempted to explain away by rationalizing that the people of Caernarfon had elected to watch the investiture on television. Acts of protest, both violent and nonviolent, were legion. Union Jack flags_-seen as symbols of Britishness, and therefore antithetical to Welshness-were stolen from flagpoles during investiture week. ${ }^{7}$ There were two explosions in the town-one fortunately caused no injuries, but the other destroyed a military police van, killing a serviceman. ${ }^{8}$ A third explosion on July 5 , the result of a faulty bomb that had failed to go off during the procession, seriously injured a boy. ${ }^{9}$ A few nonviolent protesters were arrested on the day. Some of them carried placards with the Welsh slogan "Cymru nid Prydain" (Wales not Britain) while others booed and made obscene gestures at the royal carriages. ${ }^{10}$ One threw an egg at the Queen's carriage as it passed by, ${ }^{11}$ and another threw a banana skin under the feet of the military escort as it processed. ${ }^{12}$ As John Davies put it, however, in general terms, "the investiture won extensive support among the Welsh," even if this was largely down to the fact that "all the resources of the media were in [its] favour." 13

It can be demonstrated that those in Wales most likely to be opposed to the investiture were either young, Welsh-speaking, Welsh nationalists, or a combination of all three. The anti-investiture songs of Dafydd Iwan gave voice to their feelings. As a young, attractive star of the Welsh-language pop world, then still in its infancy, a supporter of Plaid Cymru, and since late 1968, chairperson of the WLS, it would not be misleading to describe Dafydd Iwan as an unofficial spokesperson for all those who objected to the imposition of an English Prince of Wales on the Welsh. Dafydd Iwan protested in speeches and in print, but by far his most effective method of protest was through song. His popular acoustic ballad "Carlo" (1969) reads today like a gentle lampooning of the young heir to the British throne, but at the time it caused widespread outrage both within and without Wales. Columnists and commentators referred to it as

\footnotetext{
${ }^{4}$ Davies, History of Wales, 671; John S. Ellis, Investiture: Royal Ceremony and National Identity in Wales, 1911-1969 (Cardiff: University of Wales Press, 2008), 198-99.

${ }^{5}$ Davies, History of Wales, 671; Jan Morris, The Princeship of Wales (Llandysul: Gomer, 1995), 20.

${ }^{6}$ Ellis, Investiture, 242, 238.

${ }^{7}$ Caernarvon and Denbigh Herald, July 11, 1969, 12.

${ }^{8}$ Ellis, Investiture, 236 and n. 182. The fatal explosion was never claimed by any organization, and may have been accidental.

${ }^{9}$ Ibid.

${ }^{10}$ Ellis, Investiture, 235.

${ }^{11}$ Morris, The Princeship of Wales, 19.

${ }^{12}$ Caernarvon and Denbigh Herald, July 11, 1969, 4.

${ }^{13}$ Davies, History of Wales, 671.
} 
malicious, a personal attack on the prince, or as a "hymn of hate," even as others warmly praised the track and Dafydd Iwan for drawing attention to the hypocrisy and contradictions inherent in Charles's investiture. In spite of the song's extraordinary commercial success-released as a single, it became a bestseller, and broke all records for the Welsh-language pop charts-objections to the song reached such a level in some quarters that many questioned Dafydd Iwan's personal safety. ${ }^{14}$ In late May, Dafydd Iwan publicly proclaimed that his performance of "Carlo" at an anti-investiture event in mid-Wales on June 28 , three days before the investiture, would be the final time he would perform the song live, claiming that, by then, the song would have served its purpose. ${ }^{15}$

The popular and scholarly attention lavished on "Carlo," however, has resulted in the ignoring of another, equally significant song of Dafydd Iwan's that was just as revealing of Welsh attitudes towards Prince Charles and the British monarchy, if not more so. "Croeso Chwe Deg Nain" (glossed as, "Welcome 69," but see below), released as a single in July 1969, was not the runaway success that "Carlo" was, but even so, its absence from the ongoing discussions on both Welsh politics of the 1960s and studies of Welsh-language popular music of the period is startling. John Ellis's exhaustive analysis of Welsh national identity and the investitures of Princes of Wales in the twentieth century (2008) mentions "Carlo" and Dafydd Iwan on several occasions, but ignores "Croeso Chwe Deg Nain" completely; and while Sarah Hill, in her ground-breaking study of Welsh-language popular music (2007), devotes three pages to an analysis of "Carlo," she affords a only single sentence to "Croeso Chwe Deg Nain." ${ }^{16}$ Similarly, E. Wyn James's masterful analysis of Iwan's substantial body of "protest ballads" (2005) foregrounds "Carlo" while failing to mention its successor at all. ${ }^{17}$ Only Carwyn Fowler (2005) accords the song any importance, describing it as being "at least as hard-hitting as 'Carlo"”- a viewpoint I endorse and will explicate further. $^{18}$

This general neglect of the song can doubtless be traced (at least in part) to the more affectionate, farcical atmosphere that it projects, a facet of the ballad that Dafydd Iwan was quick to point out. However, to dismiss it as a pale imitation of "Carlo," or worse, as an afterthought- the single was, after all, released a fortnight following the investiture-would be to overlook the substantial rhetorical force of the song. Unlike "Carlo," "Croeso Chwe Deg Nain" peers inward, entailing an examination of what Dafydd Iwan habitually referred to as the "ymlyniad [t] aeogaidd" (servile adherence) of the Welsh towards the British monarchy, an adherence that, in his opinion, would need to be expunged from the Welsh psyche in order for Wales as a nation to realize its true potential and achieve both political and cultural independence.

The object of this article, then, is to redress the imbalance. It entails an account of the circumstances surrounding Dafydd Iwan's response as both nationalist and songwriter to the investiture, a tentative textual history of "Croeso Chwe Deg Nain" drawing on written and audiovisual sources, and finally, an analysis of audience reaction to the song as encapsulated in its music video, which has until now lain neglected in the BBC's archives. It will be demonstrated that, even as Dafydd Iwan was at pains to stress the ballad's status as a "comic song," there were those in Wales who were not only prepared to find

\footnotetext{
${ }^{14}$ An (unfounded) rumor circulated on the day the of investiture that Dafydd Iwan had been assaulted by people opposed to his views, and had to be taken to hospital. Ellis, Investiture, 242.

${ }^{15}$ Y Cymro, May 28, 1969, 7.

16 'Blerwytirhwng?': The Place of Welsh Pop Music (Aldershot: Ashgate, 2007).

17 "Painting the World Green: Dafydd Iwan and the Welsh Protest Ballad," Folk Music Journal 8 (2005): $594-618$.

${ }^{18}$ Carwyn Fowler, 'A Typology of Nationalism in Welsh rock/folk music', paper presented at PSA Annual Conference, University of Leeds, 4th-7th April.
} 
political resonances in the song's text, but were in positions to offer interpretations of the song's meaning that affected audience responses to it at the most fundamental level.

\section{Overview: Dafydd Iwan's early career}

Virtually unknown outside Wales_and sometimes unacknowledged even in English-speaking areas of Wales, in spite of his later career as a successful businessman and nationalist politician-Dafydd Iwan may nonetheless be understood as "a figure of international significance, both as an embodiment ... of the singer-songwriter par excellence and as a concrete example of the power and influence of popular song." 19 Born Dafydd Iwan Jones in 1943 in Brynaman in south Wales, but raised in north Wales near the Welshspeaking market town of Bala, Dafydd Iwan had been assisted in his rise to the top by numerous appearances on Welsh television. After famously honing his craft by the campfires at summer camps for young Welsh speakers in the early 1960s, by 1965 he had attracted the attention of the producers of television program Y Dydd (The Day), the Welsh-language news magazine, which came to an end every night with a musical item. At a time when very little Welsh-language programming was broadcast on television, the few programs that did appear were naturally highly anticipated, and regularly achieved very high viewing figures among Welsh speakers. Dafydd Iwan's performances of adaptations of songs by Pete Seeger and Woody Guthrie around this period made him a firm favorite with Welsh-speaking audiences, and placed him at the forefront of the emerging generation of Welsh-speaking acoustic pop artists (see below). Also in this year, Dafydd Iwan released the first of his records on the Welsh Teldisc label, the EP Wrth Feddwl Am Fy Nghymru (While Thinking About My Wales), ${ }^{20}$ which proved a roaring success, selling ten thousand copies ${ }^{21}$ and creating, to a very substantial degree, the audience for acoustic Welshlanguage popular music; one commentator noted in 1969 that the record was for many the first Welshlanguage pop record they had ever bought. ${ }^{22}$ In June 1966 Dafydd Iwan-then just twenty-three-had been given his own variety television program, Dyma Dafydd (Here's Dafydd) on the TWW channel, and in spite of an initially lukewarm reception from critics, ${ }^{23}$ his reputation continued to increase.

"Wrth Feddwl Am Fy Nghymru" had set the tone for Dafydd Iwan's work and, not incidentally, prefigured his later indignation at Prince Charles's investiture. A deeply patriotic and melodious ballad, the emphasis was not on Dafydd Iwan's rudimentary guitar work but his mellifluous voice, as he eulogized the medieval Welsh princes Llywelyn II (d. 1282) and Owain Glyndŵr (d. c. 1415), the Welsh language, and the Welsh landscape-all, in his eyes, quintessential carriers and maintainers of Welsh identity:

Rwy'n cofio Llywelyn, byddinoedd Glyndŵr

Yn ymladd dros ryddid ein gwlad,

Ond caethion y'm eto dan bawen y Sais,

Mor daeog, mor llwm ein hystâd.

\footnotetext{
${ }^{19}$ James, "Painting the World Green," 594.

${ }^{20}$ Dafydd Iwan, Cân dros Gymru (Caernarfon: Gwasg Gwynedd, 2002), 30-35, provides a useful overview of Dafydd Iwan's stint on Y Dydd and his first record; see also Hill, Blerwytirhwng, 59.

${ }^{21}$ Hill, Blerwytirhwng?, 209.

${ }^{22}$ Asbri 1 (May 1969), 5. Dafydd Iwan's report in his memoirs that he and Edward Jones recorded his debut EP not in a professional studio but in the bar of a sports and social club in the tiny village of Creunant on a single microphone one Sunday morning is an indication of how ill-formed and unsophisticated the Welsh-language pop industry was at this time (Cân dros Gymru, 35).

${ }^{23}$ Y Cymro, July 7, 1966, 16.
} 
Ac wrth feddwl am fy Nghymru

Daw gwayw i 'nghalon i,

Dyw'r werin ddim digon o ddynion, bois,

I fynnu ei rhyddid hi.

Wrth edrych o'th gwmpas fe weli

Fod yr heniaith yn cilio o'r tir,

Ni chlywir yr un acen, ni chlywir yr un gair

O iaith ein cyndadau cyn hir...

(I remember Llywelyn, Glyndŵr's armies

Fighting for our country's freedom,

But we are still slaves under the thumb of the English,

So servile, so bleak our condition.

And while thinking about my Wales

A pain stabs my heart,

The gwerin ${ }^{24}$ aren't man enough, boys,

To insist on its freedom.

As you look around, you'll see

That the old language is receding from the land,

Not one sound, not one word

Of our forefathers' language will be heard before long ... . $)^{25}$

This extraordinary conflation of three separate elements of Welsh identity-landscape, language, and history-is entirely typical of Dafydd Iwan's early output. Wyn James situates the singer around this time within the context of what he calls the "second' English folk revival," ${ }^{26}$ itself informed by the works of Seeger and Guthrie, which took hold in the early 1960s, and which had its corollary in Wales, especially in the university cities such as Bangor, where jazz and folk clubs were shortly established. At the same time, however, James acknowledges this connection as problematic, "partly because of the wider variety of cultural influences and developments involved and the wider range of participation and perceptions." ${ }^{27}$ Much work remains to be done in this regard. Welsh popular music of the 1960s and early 1970s took its cues from England, America, and the European continent; from the other Celtic countries, particularly Ireland (a mere two hours' sailing from the western ports) and Brittany (where many folk musicians such as Alan Stivell sang in another of the Brythonic Celtic languages, Breton) ${ }^{28}$ and from earlier indigenous popular music traditions. At the time that Dafydd Iwan was releasing his first records, they had to compete on the Welsh-language pop charts with those of folk musicians, choirs, female and mixed vocal harmony groups, child acts, and instrumentalists of every sort. ${ }^{29}$

\footnotetext{
${ }^{24}$ A difficult term to render; it translates literally as "folk," but has a particular nuance, reflecting Welsh social structure. Prys Morgan, in his lengthy survey of the term's meaning, considers a concise English translation impossible; see "The Gwerin of Wales - Myth and Reality," in The Welsh and their Country, ed. I. Hume and W.T.R. Pryce, 134-52 (Llandysul: Gomer, 1986), 134.

${ }^{25}$ Dafydd Iwan, 'Wrth Feddwl Am Fy Nghymru' (Welsh Teldisc, 1966). All translations are my own.

${ }^{26}$ James, "Painting the World Green," 608.

${ }^{27}$ Ibid.

${ }^{28}$ For example, a "Pan-Celtic Song Festival" was established in Killarney, Ireland, in 1970; Welsh musicians participated from the outset. Asbri 18 (October 1972), 6.

${ }^{29}$ Hill, Blerwytirhwng?, 51-58 gives an invaluable survey of Welsh-language popular music and its multifarious strands before the 1960s.
} 
Nevertheless, by 1968 Dafydd Iwan had firmly established himself as one of the leading figures in the emerging wave of Welsh-language musicians playing in the acoustic style of Bob Dylan, Donovan, and Pete Seeger: singers such as Huw Jones, Heather Jones, and Meic Stevens, and bands such as Y Tebot Piws (The Purple Teapot), followed Dafydd Iwan's lead, writing on patriotic themes such as the independence issue, the language struggle, and the Tryweryn affair. The upcoming investiture of Prince Charles would prove to be, like the drowning of Tryweryn, an extremely emotive issue. It had come to the attention of the Welsh public late the previous year, with the launch of the "Croeso '69" (Welcome '69) campaign, a drive to organize celebrations, special events, and parties across Wales in 1969 to honor the prince ahead of the investiture. ${ }^{30}$ The campaign, initiated by the Welsh Tourist Board at the prompting of the Welsh Office - an arm of the Labour government then in power in London, and increasingly fearful of nationalist stirrings in Wales ${ }^{31}$ — was broadly supported by civic institutions across Wales, and a vigorous publicity campaign was conducted in Australia and America in particular in an effort to attract tourists to Wales for the occasion. ${ }^{32}$

Had the investiture been a perfunctory and quickly organized affair, it might never have achieved notoriety. In Welsh nationalist eyes, however, its more or less continuous presence as a news story in the Welsh press was understood as exerting a pernicious influence on the Welsh people, militating against the principles of self-determination and cultural revival that Plaid Cymru were attempting to exploit, and binding them ever more closely to an English establishment revolving around a barycenter that lay somewhere between the Houses of Parliament and Buckingham Palace, and which the bitter experience of Tryweryn had shown cared little for either the Welsh people or their nationhood. As Dafydd Iwan himself expressed it in an early autobiography, the Welsh would never be free until they rid themselves of the "agwedd wasaidd . . . tuag at Goron Lloegr" (servile attitude . . towards the English Crown). ${ }^{33}$

With such a long lead time between the planning for the investiture and the event itself, it is hardly surprising that the subject of the investiture was considered by Dafydd Iwan well before the spring of 1969. Both "Carlo" and “Croeso Chwe Deg Nain” did, in fact, have a direct precedent in Dafydd Iwan's earlier work. They represented the continuance and culmination of the process of developing responses to the investiture that Dafydd Iwan had embarked upon in October 1968, with the release of his seventh record, the Cân Y Medd (Song Of The Mead) EP. Following the pattern of his earlier efforts, the record contains a mixture of traditional folk melodies and settings of poems by noted Welsh poets, such as $\mathrm{T}$. Gwynn Jones, and original compositions. The EP's second track, "Tri Mis O Ddathlu Mawr" (Three Months Of Great Celebrating), was a collaborative effort between Dafydd Iwan and Robat Gruffudd, a fellow language campaigner and poet, and owner of the Y Lolfa printing press that had begun to publish highly successful editions of the sheet music for Dafydd Iwan's songs the previous year. ${ }^{34}$ From a musical standpoint, it was the least inspired of Dafydd Iwan's songs on the investiture, and it comes as no surprise that the song was one of the few dating from the earliest period of Dafydd Iwan's career that was never published or re-released. However, the subject matter clearly fascinated Dafydd Iwan, who grasped the

\footnotetext{
${ }^{30}$ Ellis, Investiture, $175-77$.

${ }^{31}$ John Davies, History of Wales, 667, notes that two parliamentary seats that had been Labour strongholds for decades were almost lost to Plaid Cymru candidates in 1967 and 1968. James Griffiths, a prominent Labour politician and the first Secretary of State for Wales, even expressed the fear that the party would soon replace Labour as the dominant political force in Wales (ibid.).

${ }^{32}$ Ellis, Investiture, 176.

${ }^{33}$ Dafydd Iwan, Dafydd Iwan (Caernarfon: Gwasg Gwynedd, 1981), 46.

${ }^{34}$ For notice of the record, Y Cymro, October 24, 1968, 7.
} 
possibilities for advancement of the nationalist cause that lampooning the investiture afforded, as he noted in conversation at the time:

Cân i'w chymryd yn ysgafn, ... fel yr Arwisgo ei hun, a phob gwagedd arall. Y drwg ydy y bu ystyr a phwrpas difrifol i Dywysog Cymru unwaith.

([It is a] song to be taken lightly, ... like the Investiture itself, and every other vanity. The shame is that there was meaning and a serious purpose to [the role of] Prince of Wales once. $)^{35}$

The Cân YMedd EP was, by Dafydd Iwan's high standards, a relative disappointment, and was the first EP released by him to fail to reach the top of the "Deg Uchaf" (Top Ten) pop chart published in Wales's most popular Welsh-language newspaper, the weekly Y Cymro (The Welshman), since late 1967. Achieving a highest placing of number three, it spent just under three months mostly in the lower reaches of the chart before disappearing in January 1969. By that time, however, he had already penned a successor that was to have an immeasurably longer-lasting impact.

\section{"Carlo"}

The weeks leading up to the release of "Carlo" in late January 1969 were busy for Dafydd Iwan. Although a Christmas single recorded with sometime accompanist Edward Jones had performed poorly in the charts, ${ }^{36}$ Dafydd Iwan remained in the public view, both as a singer and as chairperson of the WLS, a role he had taken on the previous October. ${ }^{37}$ He made a well-received appearance alongside Mary Hopkin—who had in 1968 left her Welsh-language singing behind to sign to the Beatles' Apple label, and achieved a number one hit in the UK (and a number two in the US) with "Those Were The Days"-and Amen Corner on HTV's Welsh-language popular entertainment program, '04, '05 Ac Ati ('04, '05 Etc.), on December 30, 1968; a further appearance on the program would follow in April. ${ }^{38}$ In the meantime, Dafydd Iwan was in constant demand for live engagements. As one of a very few artists who made their living singing in Welsh, Dafydd Iwan was rarely if ever able to turn down bookings, and he travelled the length and breadth of Wales; for much of March 1969 he was engaged with Cwmni Theatr Cymru (Theatre Company of Wales), providing light musical accompaniments for their variety show Dawn Dweud (The Gift of the Gab). ${ }^{39}$

In January 1969, however, he had spared the time to record "Carlo," a satirical song articulating his anti-investiture standpoint. A tuneful ballad, the song recounts the story of the singer's "ffrind bach," or little friend ("Carlo" is the Welsh diminutive for "Charles," often used as a name for pet dogs), who is reimagined as a flag-waving Welsh nationalist, an avid reader of both the works of medieval court poet Dafydd ap Gwilym and Tafod y Ddraig (Tongue of the Dragon), the monthly magazine in which the WLS published news on its regular protests to secure civil rights for Welsh speakers. ${ }^{40}$

Released at the end of the month on the Welsh Teldisc label (Fig. 1), the single was a runaway success in the context of the nascent Welsh-language pop world. With a potential market of slightly over

\footnotetext{
${ }^{35}$ Sleeve notes, Dafydd Iwan, Cân Y Medd, Welsh Teldisc, 1968, EP.

36 “A Chofiwn Ei Eni Ef” (And We Remember His Birth), which attained a highest placing of number five. Y Cymro, December 28, 1968, 7.

${ }^{37}$ Ellis, Investiture, 205. Ellis's chronology is confused here; the assertion that Dafydd Iwan was elected on the back of the popularity of "Carlo," which had not yet been recorded in October 1968, makes no sense.

${ }_{38}$ Baner ac Amserau Cymru, January 9, 1969, 4; February 20, 1969, 4.

${ }^{39}$ Baner ac Amserau Cymru, March 6, 1969, 1; March 20, 1969, 8.

${ }^{40}$ Hill, Blerwytirhwng?, 114-17, and James, "Painting the World Green," 602-04, give analyses.
} 
540,000 Welsh speakers by 1971 (not counting a minority of monoglot English-speaking listeners), records by even the most successful Welsh-language pop artists would sell, at most, fifteen thousand copies by that time. "Carlo" was one of these early successes, selling more than thirteen thousand copies. ${ }^{41}$ Its launch was not trouble-free-ironically for a single that would go on to become one of the most famous Welshlanguage pop songs ever written, it debuted in Y Cymro's chart only at number five due to a mix-up over transporting copies to record shops in south Wales ${ }^{42}$ - but its exceptional nature soon became obvious. By mid-April it was outselling English-language records in a record shop in Oswestry, England, ${ }^{43}$ an unheardof feat for a Welsh-language single; in May it was reported that "Carlo" had broken Welsh Teldisc's previous record for monthly sales; ${ }^{44}$ and in early June it set a new record for the most consecutive weeks at number one in Y Cymro's chart.

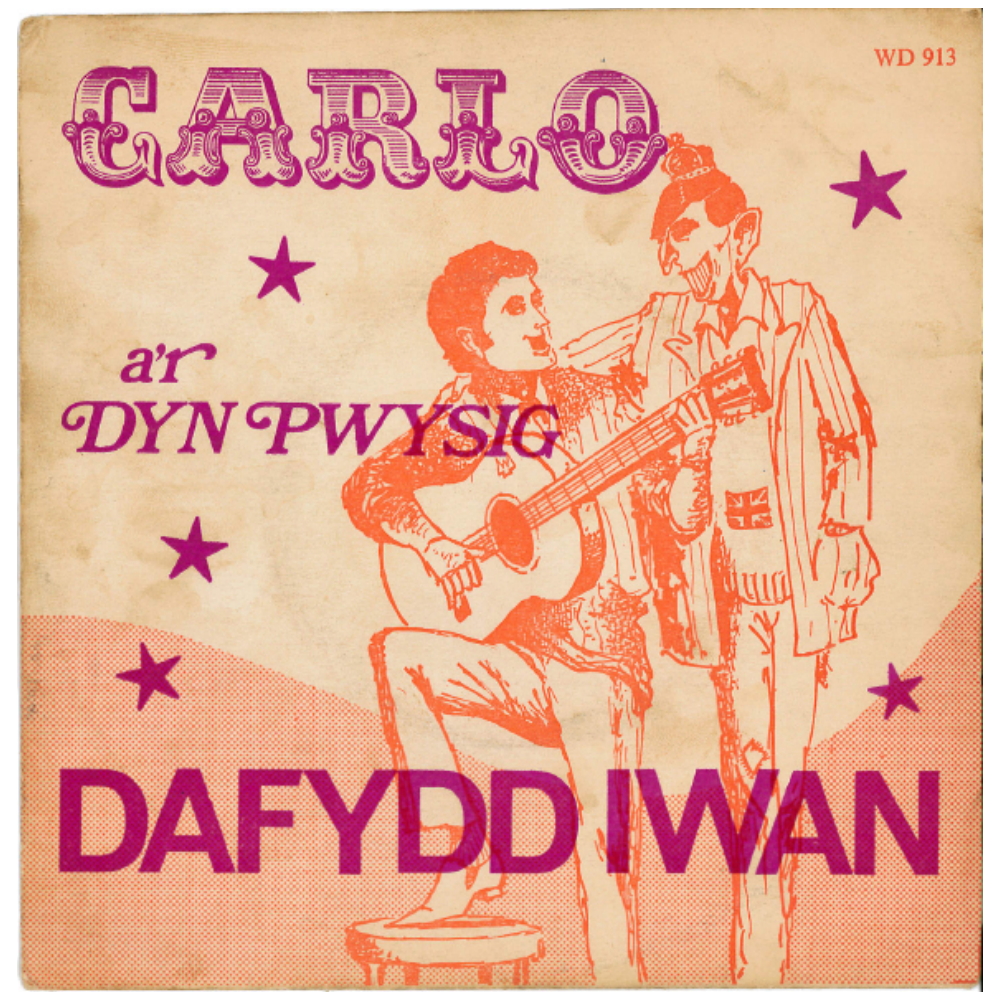

Figure 1: Cover of “Carlo” by Dafydd Iwan (1969); artwork by Elwyn Ioan

\footnotetext{
${ }^{41}$ Though surely not, as Dafydd Iwan claimed in Cân dros Gymru, all in the first week of its release (p. 43)! While there is no reason to doubt the final figure, we may infer that sales accrued more gradually; a report published in $Y$ Cymro a fortnight after its release noted that the Welsh Teldisc label would need to press more copies of the single shortly, as they had placed an initial order for less than 2,000 records (February 20, 1969, 7). Sales figures for the early period in Welsh-language popular music are hard to come by, but Dafydd Iwan implies in a 1973 magazine article that sales of 10,000 were exceptional, and that a successful single would ordinarily sell around 5,000 copies. These estimates are doubtless reliable; Dafydd Iwan was joint owner of Sain Records by this time (Asbri 23 [Winter 1973], 5). At the same time, Roger Wallis and Krister Malm note that Dafydd Iwan's contemporaries, the duo Tony ac Aloma, sold around 15,000 copies of each of their records ("Sain Cymru: the role of the Welsh phonographic industry in the development of a Welsh language pop/rock/folk scene," Popular Music 3 [1984]: 83).

${ }^{42}$ Y Cymro, February 6, 1969, 7.

${ }^{43}$ Due to the fact that Oswestry was a market town three miles from the Welsh border that attracted much trade from nearby Welsh-speaking districts and had a good number of Welsh speakers among its inhabitants. Still, the shop's owner reported that only two other Welsh-language records had even made it onto the shop's own top-ten list previously. Y Cymro, April 16, 1969, 7. ( $Y$ Cymro was printed and published in Oswestry in this period.)

${ }^{44}$ Y Cymro, May 14, 1969, 7.
} 
This enormous commercial success, however, could not mask the growing criticism of the song's subject matter; and the Welsh press in particular were deeply polarized over the song's wider significance. In north Wales, where the investiture ceremony was due to take place, pro- and anti-"Carlo" parties can be discerned with relative ease. Anglesey weekly Y Clorianydd (The Assessor; it merged with another local paper, The Gazette, during the year) came down firmly on the side of the singer, with one columnist opining in March,

Pobl Cymru roddodd "Carlo" ar ben y siart. Pobl Cymru gadawodd hi ar y copa. A wyddoch chi pam? Am fod Dafydd Iwan wedi lleisio teimladau cenhedlaeth gyfan o wir Gymry. Mae'r gân yn glasur.

(The people of Wales put "Carlo"on top of the chart. The people of Wales left it at the top. And do you know why? Because Dafydd Iwan has voiced the feelings of an entire generation of true Welsh people. The song is a classic. $)^{45}$

Y Cymro, too, gave Dafydd Iwan's song a sympathetic hearing, and noted his triumphal appearance at the June 28 anti-investiture rally at the monument to the native Welsh prince Llywelyn II in Cilmeri, where the Unitarian minister and prominent public figure Reverend D. Jacob Davies had occasion to compare Prince Charles unfavorably with his satirist: "Fe ddechreua'i yn y modd arferol, trwy ddweud mai crwt neis yw'r crwt ... Roeddwn i'n cyfeirio, wrth gwrs, at Dafydd Iwan!" (I'll start in the usual way, by saying that the lad is a nice lad ... I refer, of course, to Dafydd Iwan!') ${ }^{46}$ The Baner ac Amserau Cymru (Banner and Times of Wales), meanwhile, was broadly if not enthusiastically supportive, reprinting favorable comments on the song. ${ }^{47}$

On the other hand, there was the standoffish response of the North Wales Chronicle, which did not so much lambast "Carlo" as ignore it completely, while the repeated poisonous attacks on both song and singer by Yr Herald Cymraeg a'r Genedl (Welsh Herald and Nation) became something of a cause célèbre for the Welsh pop world. Barely a fortnight after the single's release, its judgment on the song-at number nine in the paper's chart, compiled using the sales figures from three shops in Caernarfon, where the paper was based-was sneering but proportionate: it was a "shame" (truenı) that Dafydd Iwan had chosen a protest song ridiculing the royal family, and the writer doubted that the song would be a success. ${ }^{48}$ The following week, however, all restraint had been abandoned: "Carlo" now appeared the top of the paper's chart, outselling both English and Welsh-language records in Caernarfon, including those of Fleetwood Mac, The Move, and Engelbert Humperdinck, and the knives were sharpened accordingly:

Gyda chywilydd mawr, mae'n rhaid i mi gyhoeddi bod Dafydd Iwan wedi cymryd trosodd safle un yn siart Caernarfon. Cywilydd sydd gennyf o’r gân. . . . Dyma gân sydd wedi'i seilio'n hollol ar gasineb, ac ni welaf ddim yn ddigrif ynddi.

...

Yn sicr, dyma record na fu ac na fydd ar fy rhestr prynu. Felly, da chwi, trowch eich cefnau arni, ac efallai gwelir deunydd gan y cantor addawol hwn sy'n deilwng i’w phrynu.

\footnotetext{
${ }^{45}$ Y Clorianydd, March 12, 1969, 5. Diacritical marks were usually omitted in this and many other newspapers of the day; these are added silently throughout.

${ }^{46}$ Y Cymro, July 2, 1969, 13.

${ }^{47}$ March 6, 1969, 5. Intriguingly, the same issue ran a satirical poem entitled "Croeso Chwe Deg Naw" (Welcome Sixty Nine) under the nom-de-plume "Syr Crafwr" (Sir Sycophant), 6. The words do not resemble those of Dafydd Iwan's song, but the allusion-to a Welsh nation rendered servile and cringing before the monarchy-bears obvious parallels.

${ }^{48}$ Yr Herald Gymraeg a'r Genedl, February 17, 1969, 6.
} 
(With great shame, I must report that Dafydd Iwan has taken over the number one spot in Caernarfon's [pop] chart. I am ashamed of the song. ... This is a song which is based wholly on hate, and I can see nothing that is funny about it.

...

Certainly, this is a record that has not been and will not be on my buying list. Therefore, I urge you, turn your backs on it, and perhaps we will see material by this promising singer that is worthy of being purchased. $)^{49}$

Sanctimonious, morally proscriptive, and condescending-for calling a singer who had several successful singles, a bestselling songbook already in its second edition, and his own television series "promising" can only be described thus-this article calls for further comment. The shift from opinion piece to polemical tract is pronounced; and Dafydd Iwan may well be right in his suggestion that pressure had been brought to bear by the editor, John Tudor Jones (a future Conservative Party candidate for Anglesey), on the newspaper's usual pop columnist—or that copy had been overhauled or ghost-written by someone elsewith the aim of presenting reports that cast Dafydd Iwan in an unfavorable light. ${ }^{50}$ Similar critical comments continued to be published by the paper into March. ${ }^{51}$ Writing in English in the other newspaper he edited, the Caernarvon and Denbigh Herald, Jones went even further, describing "Carlo" as a "hymn of hate," "very poor stuff and in very bad taste." 52

This scathing condemnation was a common reaction among those in favor of the investiture, and Dafydd Iwan's subsequent pronouncements, as well as his frank admission that he received innumerable pieces of hate mail during this period, ${ }^{53}$ make clear the depth of their displeasure. One of the most revealing incidents to occur during the spring of 1969 was the singer's performance of the song for the pop program Disc a Dawn (Disc and Talent). First aired in 1966, Disc a Dawn functioned as a Top of the Pops-type program for Welsh-language artists, featuring live performances by popular artists, the occasional music video (a medium that was then, as in England, in its infancy in Wales, but see below), and a rundown of $Y$ Cymro's pop chart every week. As "Carlo" was at number one for all but one week during the spring of 1969, Dafydd Iwan featured prominently during this period, and he performed two songs in the studio for the May 9 edition. ${ }^{54}$

Two aspects of this performance of "Carlo" underline the politically sensitive nature of the song. Firstly, there is Dafydd Iwan's alteration of a lyric that detractors found particularly irksome. The song's final verse, cranking up the satirical content to new levels, names "Carlo" as being connected with the FWA (Free Wales Army), an extremist group responsible for several bombings in Wales at the time. Though a plainly preposterous suggestion, the juxtaposition of prince with extremist was too much for some; and when Dafydd Iwan reached the line, he smeared the acronym: "FWA" becomes "FLA." It is hard to know how premeditated an act this was. Perhaps the singer was himself undecided until the last possible moment, for what comes out certainly has an air of spontaneity to it, and spoils the melody's rhythm, suggesting a hurried improvisation. If it was the result of a deliberate strategy rather than a flub, prudence may well have dictated it. Since mid-April, a number of FWA members had been on trial at

\footnotetext{
${ }^{49}$ Yr Herald Gymraeg a'r Genedl, February 24, 1969, 6.

${ }^{50}$ Cân dros Gymru, 45.

${ }^{51}$ For instance, the description by "Elfed" of Dafydd Iwan as "pregethu casineb" (preaching hatred); March 3,1969, 6.

${ }^{52}$ Quoted in Dafydd Iwan, Cân dros Gymru, 48.

${ }^{53}$ Cân dros Gymru, 48.

${ }^{54}$ Very few editions of Disc a Dawn dating to before 1970 are known to have survived, and I am grateful to the staff of the British Film Institute in London, as well as the staff of the BBC in Caversham and Cardiff, for their assistance in locating and allowing me access to this and other film recordings referred to in this article.
} 
Swansea court, the proceedings of which made the newspapers on a daily basis. ${ }^{55}$ The possibility of a contempt of court charge may well have informed the singer's attitude towards his composition.

Secondly, at the song's conclusion, presenter Ronnie Williams joined Dafydd Iwan for a brief interview:

Williams: Ti 'di cael dy feirniadu yn go hallt am y record yma yn bersonol felly. Ydy'r math yma o beth yn dy ypsetio di o gwbl?

Dafydd Iwan: O na, dach chi'n disgwyl beirniadaeth pan fydd y pwnc ychydig bach yn gontroversial, yn bwnc llosg fel hwn, ynde? Ond ma' ychydig bach o['r] feirniadaeth 'ma wedi bod [yn] dra phersonol, ac ychydig bach yn annheg weithiau, ond dw i ddim yn colli cwsg.

(Williams: You've been slated quite severely for this record, and that on a personal level. Does this sort of thing upset you at all?

Dafydd Iwan: Oh no, you expect criticism when the subject is a little bit controversial, a hot potato like this, don't you? But a little bit of this criticism has been very personal, and a little bit unfair sometimes, but I'm not losing any sleep.)

Nevertheless, Dafydd Iwan's reception at live appearances during this period could not be counted upon. When playing to his natural constituency—nationalists, patriots, and adherents of the Welsh pop worldhe was in his element: a concert organized by Plaid Cymru in Carmarthen on May 18, at which he appeared alongside singers Iris Williams and Doreen Davies among others, was sold out over a week beforehand; it was attended by over two thousand people, including the town's mayor and the Plaid Cymru Member of Parliament, Gwynfor Evans, who made a speech. ${ }^{56}$ However, the response of some audiences could be far more combative. During a concert in the village of Pencaenewydd, near Pwllheli, during the Easter holiday, the response to Dafydd Iwan was such that he felt compelled to mount a defense of "Carlo" and his own character: allegations had been made, he said, that he sung out of "malice and spite," and he denied their truthfulness. ${ }^{57}$ On another occasion, a concert organizer who had booked the singer paid him not to perform, for fear of attracting protesters. ${ }^{58}$

"Carlo" was destined for a swift execution. Its status as propaganda was denied by Dafydd Iwan, but by May he had nevertheless determined that it had outlived its usefulness, and announced that he would perform it for the final time at an anti-investiture pop concert sponsored by the WLS to be held on June 28 , three days before the investiture. ${ }^{59}$

As the dust settled, some commentators began to analyze the wider significance of "Carlo." In May, Dafydd Iwan had gone on record as saying that the Welsh were "immature" in their attitudes towards satire. And writing the week after the investiture, a columnist for Y Cymro echoed this comment, opining that the royal family's high standing combined with a failure to appreciate the song's satirical aspects resulted in a tendency to attribute to the song (and its singer) the characteristics of a personal attack. Lacking the ability (or the inclination) to correctly process the song's ironic cues, unsympathetic listeners glossed the song's descriptions of the young prince in other ways:

\footnotetext{
${ }^{55}$ Martin Johnes, Wales since 1939(Manchester: Maunchester Univerasity Press, 2012), 236, notes that the trial's end was timed to coincide with the investiture in July.

${ }^{56}$ Carmarthen Times, May 3, 1969, 7.

${ }^{57}$ Y Cymro, April 16, 1969, 7.

${ }^{58}$ Hefin Wyn, Be Bop a Lula'r Delyn Aur: Hanes Canu Poblogaidd Cymraeg (Talybont: Y Lolfa, 2002$), 98$.

59 Y Cymro, May 28, 1969, 7. Nevertheless, after 1969, the song, and "Croeso Chwe Deg Nain," regularly reappeared on Dafydd Iwan's set lists in response to popular demand. The latter was dropped in later years, however. Dafydd Iwan, personal communication with the author, November 20, 2012.
} 
Efallai ei bod yn rhy amserol! Derbynnir caneuon am ryddid cenedlaethol ac ymreolaeth yn llawer rhwyddach gan eu bod yn sôn am beth mor annelwig nad oes dyddiad penodedig iddo. Ond [r]oedd 'Carlo' yn taro. Gan fod Cymry yn derbyn y frenhiniaeth fel sefydliad na ddylid byth ei ddychanu a'i ddifrio 'roedd Dafydd Iwan yn pechu'r anfaddeuol wrth ganu mor ddychanol. Aeth yn frwydr rhwng Charles a Dafydd, peth na fwriadwyd i'r gân fod erioed - y "ffrind bach" yn erbyn y canwr.

(Perhaps [the song] was too timely! Songs about national freedom and self-government are received far more freely as they talk about something so ill-defined that no specific date attaches to it. But "Carlo" hit a nerve. As the Welsh accept the monarchy as an institution that should never be satirized or made fun of, Dafydd Iwan committed an unforgivable sin by singing so satirically. It became a battle between Charles and Dafydd, something that was never intended for the song-the "little friend" against the singer.) ${ }^{60}$

Nevertheless, from a purely commercial standpoint, Dafydd Iwan emerged triumphant: as the graph below demonstrates, "Carlo" was far and away the best-performing single of 1969 in Y Cymro's chart.

Movements of three Dafydd Iwan records in Y Cymro's pop chart, JanuaryNovember 1969
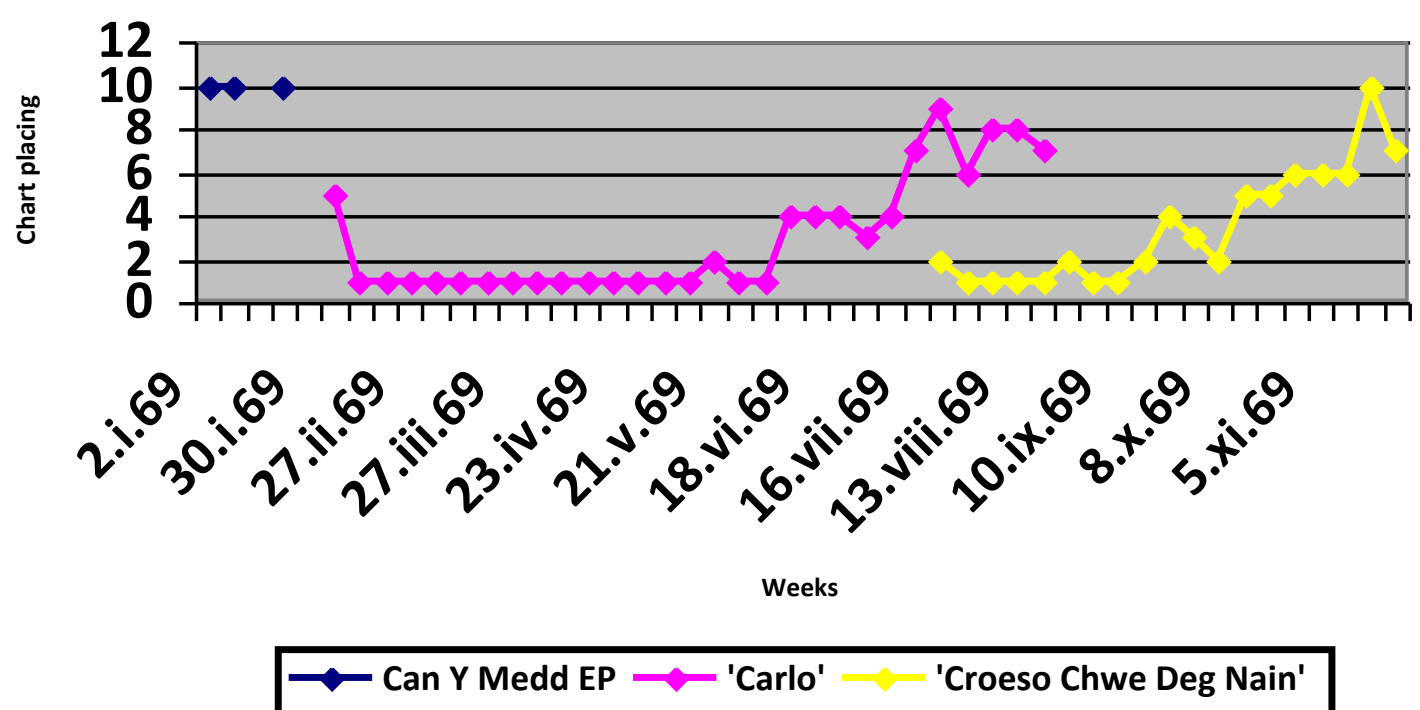

\section{"Croeso Chwe Deg Nain"}

There was a general agreement in the press that Dafydd Iwan's follow-up to "Carlo," "Croeso Chwe Deg Nain," represented, if not a rolling-back of his position towards the investiture, then at least a softening of tone. Dafydd Iwan himself was complicit in this, offering the song as a "cân digri... gydag wyth o benillion mor ddigri â phosibl" (a comic song . . . with eight verses that are as funny as possible"). ${ }^{61}$ Yet an analysis of the song's text, its reception history, and the music video that accompanied it denies this conclusion. "Croeso Chwe Deg Nain" is undoubtedly comical, even down to the bilingual play on words

\footnotetext{
${ }^{60}$ Y Cymro, July 9, 1969, 7.

${ }^{61}$ Y Cymro, July 16, 1969, 7.
} 
in the title: "chwe deg" is "sixty" in Welsh, and "nain," sounding like the number "nine" in Englishrather than "naw," the number "nine" in Welsh—finishes off the allusion to the "Croeso 69" campaign that celebrated the investiture; but "nain" is also the word used in north Wales for "grandmother": hence "Welcome, Sixty[-year-old] Gran"). However, as shall be seen, its message was just as hard-hitting as that of "Carlo."

The song's premise is, superficially at least, simple. The location is a typical Welsh village, and the investiture celebrations are in full swing. The song has eight verses in total, but only the first and the final four are given below. ${ }^{62}$

Mae pawb wedi meddwi, mae Taid ar y sbri,

Mae cath drws nesa' ar ôl cath ni

Mae llun y Duke of Norfolk uwch ben y lle tân,

A mam tu ôl i’r piano yn canu 'Calon Lân'.

Croeso chwe deg Nain, croeso chwe deg Nain

Mae Nain yn naw deg yn dweud ei bod yn chwe-deg,

A dannedd gosod Taid ym myg y Prins.

Cymanfa fawr y pentre sy'n rhan o'r hwyl a'r sbri,

A phawb o'r capel nesa' yn dod i'n capel ni,

Daeth modryb o America a modryb o Siapan

I ganu 'Haleliwia' i frawd bach Princess Anne.

Mae'r fuwch yn y beudy yn brefu am y llo,

A 'does dim angen gofyn beth fydd ei enw o

Ond mae'r hwch fawr gefn-ddu yn gwrthod cael moch bach,

Am ei bod hi'n gwrthwynebu cymryd rhan yn y strach!

Ffenestri wedi'u paentio yn goch a gwyn a glas,

A llun y Cwîn o'r cwtsh-dan-stâr wedi cael dod mas,

Llun Lloyd George yn y pasej, a'r Diwc ar yr hen focs te,

Ond mae'r babi wedi stico chewing-gum yn groes i’w lygad dde!

Mae Mam wedi dysgu'r plant bach drwg sy' wedi mynd oddi ar y rêls,

I ganu mewn falsetto 'God Bless The Prince of Wales',

Mae'r ffys wedi hala Wili'n od - mae'n siarad hefo fe'i hun,

A Maltilda yn y bathrwm yn dysgu 'God Save The Queen'.

(Everyone's drunk, Taid's ${ }^{63}$ on the spree,

Next-door's cat is after our cat,

A picture of the Duke of Norfolk ${ }^{64}$ is above the fireplace

And Mam's behind the piano, singing "Calon Lân."65

Welcome 69, welcome 69,

Nain is ninety, but saying that she's sixty,

And Taid's false teeth are in the Prince's mug! ${ }^{66}$

${ }^{62}$ As rendered in Holl Ganeuon Dafydd Iwan (Y Lolfa: Talybont, 1992).

${ }^{63}$ The word for "grandfather" in north Wales.

${ }^{64}$ Bernard Marmaduke Fitzalan-Howard, 16th Duke of Norfolk (1908-75), who oversaw the investiture ceremony.

${ }^{65} \mathrm{~A}$ famous Welsh hymn that extols the virtues of a pure heart and simple living. 
The village's big cymanfa ${ }^{67}$ is part of the fun and games

And everyone from the next chapel is coming to our chapel

An aunt came from America and an aunt from Japan

To sing "Hallejujah" to Princess Anne's little brother!

The cow in the cowshed is lowing for the calf ${ }^{68}$

And there's no need to ask what its name will be,

But the big black-backed sow is refusing to have piglets

As she is opposed to taking part in all the bother!

Windows have been painted red and white and blue

And the picture of the Queen in the cupboard-under-the-stair ${ }^{69}$ has been allowed to come out, A picture of Lloyd George ${ }^{70}$ in the passage and the Duke's ${ }^{71}$ on the old tea box

But the baby's stuck chewing gum over his right eye!

Mam's taught the bad little children who've gone off the rails

To sing in falsetto "God Bless the Prince of Wales"; ${ }^{72}$

The fuss has struck Willy oddly—he's talking to himself

And Matilda's in the bathroom learning "God Save the Queen”!)

The song stands as a piquant commentary on what Dafydd Iwan saw as the fundamental contradiction of being Welsh and British at the same time. The juxtaposition of Welsh hymns with English establishment figures, and of images evoking the agricultural life that remained the experience of most Welsh speakers in the language's heartlands with symbols of British identity such as the Union Jack (mentioned in the third verse) and "God Save the Queen," are designed to grate with listeners, underscoring both the Welshness of this stereotypical family and the servility associated with attitudes towards the monarchy. Whereas "Carlo" contains the multiple surreal images and incongruities of a member of the house of Windsor inculcated with the very fanaticism conservative elements of the press leveled at Dafydd Iwan, in "Croeso Chwe Deg Nain," the listener need question nothing: on the contrary, the family members depicted, though stereotypes, are those Welsh people who were happy to conform to the role that the English would have them play, and who were not merely inattentive to, but completely ignorant of, the wider debates on identity and self-determination the investiture engendered. Here, then, was where Dafydd Iwan hoped his listeners would be cut to the quick: after all, how many could honestly say they knew no one who would acquiesce in the investiture and submit themselves to the symbolic sleight of hand that was so inimical to the nationalists' cause?

\footnotetext{
${ }^{66}$ Commemorative cups and mugs bearing the prince's likeness were sold as souvenirs across Wales; indeed, a BBC television program had borne the brunt of censure earlier in 1969 for airing a spurious item that supposedly depicted an anti-investiture "mug-smashing competition." The Gazette/Y Clorianydd, March 19, 1969, 1; Ellis, Investiture, $296-97$.

${ }^{67}$ The cymanfa ganu is a traditional Welsh hymn-singing festival.

${ }^{68}$ A reference to a line in the Welsh nursery rhyme 'Dacw mam yn dwad'.

${ }^{69}$ A cupboard under a staircase, a common feature in Welsh (and British) houses, variously rendered in British English as a "glory-hole" or "spence," and in Welsh English as a "spench" in the north, and as a "cwtsh" in the south.

${ }^{70}$ David Lloyd George (1863-1945), the first (and so far only) Welsh Prime Minster of Great Britain (1916-22), and who was still revered in Liberal circles in Wales in the 1960s.

${ }^{71}$ Doubtless a reference to the Duke of Edinburgh, i.e., Prince Philip (b. 1921), the Queen's consort.

${ }^{72}$ Written in 1862, and performed in public for the first time in 1863, to coincide with the marriage of the Prince of Wales that year; Huw Williams, Canu'r Bobol (Gwasg Gee: Dinbych, 1978), 38-39. The work has intermittently been advanced as an Anglophone (and royalist) alternative to Wales' national anthem, "Hen Wlad Fy Nhadau" (Land of my Fathers).
} 
The most stinging imagery of all, however, is to be found in Dafydd Iwan's intentionally debased use of the Welsh language. As Welsh has existed in a diglossic environment for several hundred years, English loan words are common in the lexicon, and Dafydd Iwan (among others) used them often enough in his songs. ${ }^{73}$ However, in "Croeso Chwe Deg Nain" the presence of English loan words, or Welshified versions of English terms — chewing-gum, pasej, bathrwm, falsetto and so forth—is overpowering; and they serve as an allegorical reminder of what happens to a minority culture when it rubs shoulders with another, dominant culture once too often. Even the admixture of Welsh terms for family members-mam (not "mum" or "mom"), Nain, Taid-and English given names such as Matilda was an uncomfortable reminder of the inverse snobbery that led to generations of Welsh men and women abandoning traditional Welsh names in favor of English ones throughout the twentieth century and before. ${ }^{74}$

The song was performed for the first time on May 31, 1969, in the pavilion of the Urdd Eisteddfod, ${ }^{75}$ held that year in Aberystwyth. Listening to the surviving recording of Dafydd Iwan's performance that night is a deeply unsettling experience. ${ }^{76}$ In theory, the concerts of the $\mathrm{Urdd}^{77}$ were Dafydd Iwan's natural domain; he had, after all, cut his teeth at the Urdd's summer camps in the early 1960s. Yet the Urdd organization itself had been deeply fractured by the investiture. Even as its founder, Sir Ifan ab Owen Edwards, was forced to perform a humiliating public about-face and withdraw his support for the investiture due to pressure exerted on him by the Urdd's governing committee-which had itself seen resignations over the issue of supporting the prince-older, conservative elements within the organization ignored the committee's decision and, on their own authority, extended a personal invitation to Prince Charles to deliver an address from the main stage during the organization's Eisteddfod in the last week of May. ${ }^{78}$ Charles-who had been studying Welsh for some weeks at the University College of Wales, Aberystwyth—duly accepted; and in spite of his relative unfamiliarity with the language and the presence of television cameras that would dutifully record every slip and mistake, he gave a competent (if accented) address in Welsh on the afternoon of May 31 to a crowd of six thousand (raising a smile along the way with a sidelong reference to "Carlo").

In the front row was Dafydd Iwan, ${ }^{79}$ who, as the prince was being announced, rose along with around a hundred others-mostly WLS members-and silently processed out of the pavilion carrying anti-investiture banners bearing slogans such as "Bradychwyd yr Urdd" (The Urdd has been betrayed) and "Pwy wahoddodd y Prins? Nid y Pwyllgor Eisteddfod" (Who invited the Prince? Not the [Urdd's]

\footnotetext{
${ }^{73}$ As Hill notes in "Carlo" (Blerwytirhwng?, 115).

${ }^{74}$ R. S. Thomas, Cymru or Wales? (Llandysul: Gomer, 1992), 17, launches a withering attack on the tendency to use English or Anglicized first names in Welsh-speaking society. One "Stella Mair" is mentioned in verse 2 - a reference to Stella Mair Thomas, who was chosen in 1968 as the "national hostess" of Wales for investiture year.

${ }^{75}$ Eisteddfods are competitive cultural festivals, devoted to the cultivation of Welsh-language poetry and music, and latterly of other art forms. Their roots can be traced back at least as far as 1176. The National Eisteddfod, first held in 1861, is a weeklong event held annually in August; it is the largest competitive musical event in Europe, attracting in excess of 150,000 visitors. The Urdd Eisteddfod is the youth version of the same event, held annually in May/June.

${ }^{76}$ This tape-one of the very few live recordings from the period to have survived-has never been released commercially. I am most grateful to Dafydd Iwan for giving me permission to listen to it in the course of researching this paper. All transcriptions are my own.

${ }^{77}$ The Welsh League of Youth, established in 1922 with the remit of aiding children's education and socializing through Welsh, has remained a cornerstone of a Welsh upbringing since the Second World War. Virtually all Welsh-speaking children (and many English-speaking children) have contact with it in one way or another.

${ }^{78}$ See Y Cymro, June 4, 1969, 5, for a damning report on the Urdd's decision to invite the prince.

${ }^{79}$ Dafydd Iwan and the other protesters had gained front row seats through subterfuge; a highly respected, middle-aged gentleman sympathetic to their aims booked the seats at a day's notice, claiming that they were for a party of schoolchildren. Y Cymro, June 4, 1969, 14-15.
} 
Eisteddfod Committee) ${ }^{80}$ If the standard of Charles's Welsh was shortly to be admired, the protests could not be hidden, and the prince's address was delayed by ten minutes as scuffles broke out ${ }^{81}$ and the protesters were removed. The television cameras missed nothing as the director cut to footage of several young men being carried by the limbs away from the stage. It was an incident that made the papers across Wales and Britain, but as one of the protesters pointed out, it was the actions of the older Urdd officialswho, by inviting the prince, rode roughshod over the wishes of the Urdd committee-to which the demonstrators objected. ${ }^{82}$

This distinction was lost on the crowd who assembled that evening at the pavilion. By then, the stage had been redressed for a pop concert featuring the Welsh-language pop world's most prominent acoustic artists—-singers such as the duo Tony ac Aloma, Meinir Lloyd, and Huw Jones. Four thousand peopleone of the largest crowds ever for an event of this sort-attended, ${ }^{83}$ and the evening passed without incident until Dafydd Iwan went on stage for his first set to a wall of noise. As Dafydd Iwan later recalled, half the crowd cheered their support, while half seemed intent on booing him off. In defiant mood, he prefaced his performance with a recital of a poem by Gerallt Lloyd Owen that had won the coveted chair for poetry at the Eisteddfod the previous day, one that, like Dafydd Iwan's songs, evoked the memory of the native Welsh princes and excoriated the investiture, much to the ire of older elements in the Urdd organization. For such a staid organization, the response to Dafydd Iwan's reading was extraordinary. Within seconds of beginning, conservative, older sections of the crowd-the "pwysigion" (important ones) as Dafydd Iwan called them ${ }^{84}$ — began a slow handclap, while other sections-primarily the younger Urdd members ${ }^{85}$-attempted to voice their support. Dafydd Iwan struggled to the end, and followed the poem with an equally contested rendition of "Carlo" (in which he once again glossed over the contentious "FWA" line, fa-la-la-ing over the acronym).

Returning later in the evening, Dafydd Iwan introduced “Croeso Chwe Deg Nain” thus:

Mae'r gân nesa' yma yn un newydd, ac, er... [heckling from crowd] Gadewch - rhowch gyfle i chi; [wnaeth] ${ }^{86}$ e gael chware teg 'da chi p'nawn yma. Ga' i, er [applause] . . Mae'r caneuon ysgafn 'mod i'n ysgrifennu yn achosi mwy o drafferth na'r rhai trwm. W i ddim yn gwybod pam; r'yn ni'n genedl od, wrth gwrs. Ond mae'r gân nesa' 'ma yn un ysgafn, ac, ym, ar thema y dathlu mawr r'yn ni i gyd yn ei ganol e' nawr, yng Nghymru 'ma - r'yn ni i gyd yn dathlu o fore gwyn tan nos, yn dathlu'r digwyddiad mwya' yn hanes ein cenedl fach 'ma. Ac, um ... [heckling from crowd]

(This next song is a new one, and, er... [heckling from crowd] Leave-give yourselves a chance; he had fair play with you this afternoon. May I, er [applause] . . . The light songs that I write cause more trouble than the heavy [read: "serious"] ones. I don't know why; we're an odd nation, of course. But this next song is a light one, and, um, on the theme of the big celebration that we are all in the midst of now, here in Wales-we're all celebrating from the crack of dawn 'til dusk, celebrating the greatest event in the history of this, our little nation. And, um ... [heckling from crowd])

\footnotetext{
${ }^{80}$ Ibid.

${ }^{81}$ Iwan, Dafydd Iwan, 73.

${ }^{82}$ Caernarvon and Denbigh Herald, June 6, 1969, 9.

${ }^{83}$ Iwan, Dafydd Iwan, 45.

${ }^{84}$ Iwan, Dafydd Iwan, 46.

${ }^{85}$ Peter Hughes Griffiths, in his autobiography $O$ Lwyfan i Lwyfan (Talybont: Y Lolfa, 2010), explicitly identifies Dafydd Iwan's supporters that night as the youth (122).

86 "Ga[e]th e gael" is heard here, which makes no sense. "Wna[e]th e gael" (he had), on the other hand, may easily be interpreted as a reference to the prince.
} 
The meaning of this last sentence, delivered in a knowing, ironic tone, drew another vindictive response from the crowd as Dafydd Iwan began the song. It is clear from this debut performance that the song was a new composition - though Dafydd Iwan gave an entirely competent rendition, the verse order is different from that on record, and one or two lines differed also from the final version. The first verse, lacking overt satirical comment, passed more or less without interruption, but from the second rendition of the chorus onwards, the booing - and cheering — of the crowd becomes obvious. During the third verse performed that evening (the "cow" verse above, which is the sixth verse in the published version), Dafydd Iwan was forced to begin the third line again because of the noise following his none-too-subtle dig at the prince, cut down to size as a helpless calf's namesake on the village farm; at another point, he inserted an extra bar or two between lines due to hecklers; and at the verse's conclusion, the allusion between the sow that refused to give birth out of apathy, and the apathetic response of some in Wales to the investiture, caused dissension to break out once again: attempts by some to support the singer through raucous applause were balanced by those who tried to shout him down. Nevertheless, by the end of the song it is clear that he had succeeded in winning over the majority of the crowd-the final rendition of the chorus is even accompanied by a communal handclap, and the round of applause at the end (in recognition of his stamina, perhaps) is sustained and heartfelt.

There may, too, have been a collective sense of relief; certainly, on the face of it, Dafydd Iwan's latest work did not incorporate the same stinging observations as "Carlo" did. This view was shared by commentators, including music journalist Huw Evans, who wrote of "Croeso Chwe Deg Nain": "Tra medrir dweud efallai fod rhyw fymryn o ymosodiad personol ar y tywysog yn 'Carlo' mae hon yn gân ddiniwed, llawn hiwmor a ddylai apelio at bawb" (Although one could perhaps say that there was some hint of a personal attack on the prince in "Carlo," this is an innocent song, full of humor that should appeal to all $) .87$

This reading cannot be accepted, however, without some qualification. Certainly, "Croeso Chwe Deg Nain" was a less overtly inflammatory song than "Carlo," but this is unsurprising, because it differed in its choice of target. The Welsh people themselves are the subject of "Croeso Chwe Deg Nain," and in it, they are found wanting — all too ready to subordinate themselves to the monarchy, they eagerly take part in the festivities. ${ }^{88}$ The point was underscored in the cover artwork for the single, by satirical cartoonist Elwyn Ioan, which showed the village of the song decked out in bunting, its tipsy inhabitants singing "God Bless the Prince of Wales" at the tops of their voices (see Fig. 2, below). "Croeso Chwe Deg Nain" was, like its predecessor, a successful release. It spent six weeks in total at the top of $Y$ Cymro's pop chart and probably would have retained the spot for a little longer had the National Eisteddfod, which typically coincided with a slew of new record releases, not begun in early August. ${ }^{89}$ Nevertheless, its chart career was markedly shorter than that of "Carlo"-it dropped out of the top five at the end of October, and out of the top ten by November, as memories of the summer's events receded.

The autumn, however, brought a final twist. As Dafydd Iwan had again topped the charts, Disc a Dawn included a snatch of "Croeso Chwe Deg Nain" in their September 6 edition, accompanied by a

\footnotetext{
${ }^{87}$ Y Cymro, July 23, 1969, 16.

${ }^{88}$ In this connection, it is instructive that it was not the investiture but the Welsh themselves that were singled out for criticism in the Gerallt Lloyd Owen poem "Fy Ngwlad" (My Country) read out by Dafydd Iwan prior to his performance at Aberystwyth.

${ }^{89}$ Y Cymro, August 6, 1969, 7 presciently remarks that the record would soon drop down the charts because of the new releases.
} 
rudimentary music video. Dafydd Iwan had no involvement with this video, ${ }^{90}$ which consisted of a number of still pictures of the characters depicted in the song, drawn by an unknown cartoonist and shown in sequence using a rostrum camera. The titular Nain character, Mam and baby (chewing gum included), and Matilda singing in the bathroom all appear, among others. ${ }^{91}$

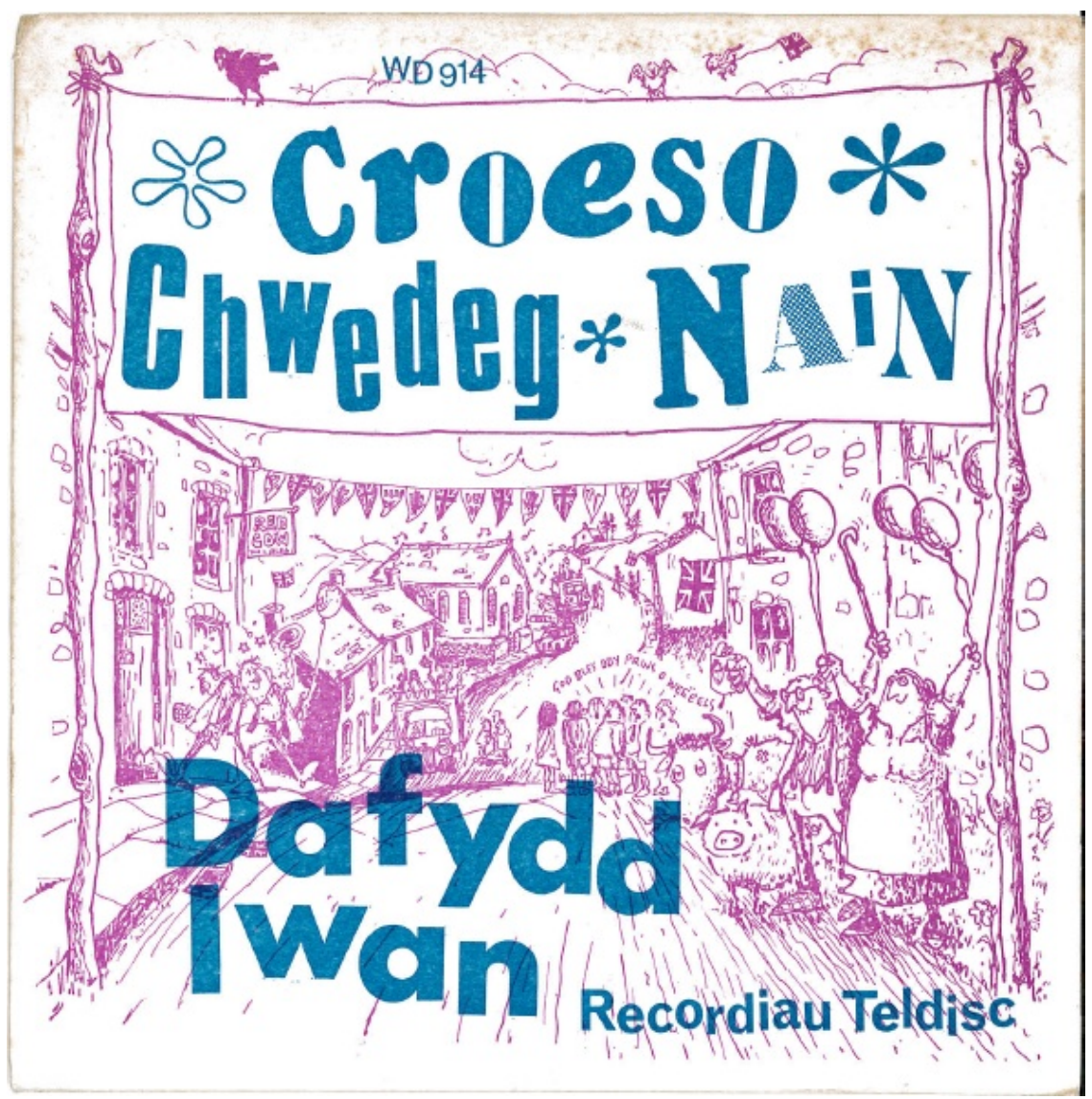

Figure 2: Cover of "Croeso Chwe Deg Nain" by Dafydd Iwan (1969); artwork by Elwyn Ioan

If we can distinguish between the syntagmatic structure of these images-their relation to the causal nature of the song, one event following another to create a narrative-and the paradigmatic structure of the Disc a Dawn program itself, on which Dafydd Iwan had performed on several previous occasions, it becomes possible to locate the decisions of the cartoonist to accentuate one aspect of the song over another more clearly. The video for "Croeso Chwe Deg Nain" recounts the events of the song; we cannot assert unproblematically, however, that this is all it does. These visuals provide a unique interpretation of the song-an interpretation that does not fully accord with Dafydd Iwan's stated purpose of writing a mere "funny tune," and one that was surely influenced by preconceived notions of how a Dafydd Iwan performance should be. Those elements whose subversive meanings are only hinted at in the song alone are here so presented as to leave no room for doubt as to their significance.

\footnotetext{
${ }^{90}$ Personal communication with the author, November 19, 2012.

${ }^{91}$ Permission was sought from the BBC to allow the inclusion of screenshots from the video in this paper, but was unforthcoming, as the copyright holder could not be identified from the surviving paperwork. I am grateful to Gwen James of the $\mathrm{BBC}$ for making enquiries on my behalf in this connection.
} 
There are two textual interpolations, in particular, that deserve comment. Firstly, there is a marked disparity between how the old and the young are portrayed-something that is entirely absent in the song's lyrics. As has been established, anti-investiture sentiment can be understood in some respects as the protest of young against old. The video, however, turns this notion on its head: whereas Mam is aghast at her baby's ruining of the Duke's picture, and her children dutifully sing in the prince's honor, it is Nain and Taid - the matriarch and patriarch of the extended family-who give knowing winks to the camera, and even play tennis using their commemorative Prince Charles mug as a ball. If the central tenet of Dafydd Iwan's song, unaccompanied by images, was "there are none so blind as those who will not see," the cartoonist makes an exception in the case of the family's grandparents. This may be read as an attempt to upbraid the oldest generation, who had indeed welcomed the prince most warmly to Wales. ${ }^{92}$ Alternately, it may be meant as a veiled criticism of the generation below-the middle-aged parents-who, unlike the irreverent Nain and Taid characters or the disinterested youngsters, give off an air of earnestness (and, it may be pointed out, ostentatious Britishness). Either way, in this fanciful reimagining, the embodiment of the whimsy Dafydd Iwan meant to convey can be located in the demeanor of the oldest generation-Nain and Taid poke fun at the investiture for the sham it is.

Secondly, there is the provocative image with which the final verse ends. During the debut performance of the song, Dafydd Iwan administered the coup de grâce to the family he depicts by resorting, quite literally, to toilet humor: the final line has Matilda sitting in the toilet while singing "God Save The Queen." This, evidently, was considered too much for the recorded version, in which "bathrwm" is substituted for "toilet" (and Matilda is busy "learning" (not "singing") "God Save the Queen"). The anonymous creator of the video, however, was clearly aware of the version dispensed with earlier; for when the line is delivered, the camera pans across from a battleship-bosomed Matilda sitting in a bubble-filled bath, surrounded by musical notes, to the toilet: an old-fashioned chain-pull affair-with a Union Jack crudely painted on the cistern. (Indeed, the camera lingers on the image for some time, making the rostrum cameraman a party to the interpretation.) If "Croeso Chwe Deg Nain" indeed represented Dafydd Iwan's attempt at placation of the royalist members of his audience, the cartoonist patently had other ideas.

Such was the video, parts of which were even shown again on Disc a Dawn's September 20 edition. ${ }^{93}$ It may, of course, be understood as a case of simple misinterpretation on the cartoonist's part-of what Eco referred to as "aberrant decoding," but writ large, because it inadvertently elevates the original song to the status of hypotext. In taking upon himself the burden of creating a visualization of Dafydd Iwan's song, the cartoonist accomplishes something else entirely, removing ambiguities and dictating the song's meaning at that point in time. Being almost certainly unaware of Dafydd Iwan's lack of involvement in the making of the video, the viewers, of course, would not have apprehended such subtleties; and bawdy cartoons with anti-monarchist and even Rabelaisian overtones could, and doubtless were, construed as being all of a piece with Dafydd Iwan's mischievous persona.

\footnotetext{
${ }^{92}$ Ellis, Investiture, 240.

${ }^{93}$ And, for all we know, on the September 13 edition as well-this was the last week the song spent at number one. The episode is no longer extant, however.
} 


\section{Conclusion}

The ramifications of the above hostile reactions to these songs were far-reaching, and ultimately selfdefeating. Writing as long ago as 1970, R. Serge Denisorff identified three characteristics that listeners felt helped constitute an efficacious protest song: that it was meaningful, original, and "saying something." All three applied in the case of both "Carlo" and "Croeso Chwe Deg Nain." However, the fault of John Tudur Jones and fellow detractors of Dafydd Iwan's songs was not that they failed to identify his opposition to the investiture in these connections but rather that their interpretations of that opposition were entirely reductive: they failed to admit the possibility that he might have any constructive or critical intentions in the first place. Confusing (perhaps intentionally in some cases) jocularity with disrespect and opposition to the constitutional position of the prince with opposition to the prince himself, they sought to gloss "Carlo" as "preaching hatred"; they misconstrued "Croeso Chwe Deg Nain"-probably the more subversive of the two songs-as a harmless farce; and, in the face of the massive success of both records, painted the record-buying audience as unsophisticated, pliable, and ignorant of Dafydd Iwan's true intentions. ${ }^{95}$ These constituted serious lapses of judgment, reflecting the deeply concerned and illconsidered reactions of a sector of Welsh society that felt undermined and threatened by any and all opposition to what they saw as a great moment in Welsh public life. Their characterization of light, tuneful songs as being hate-filled and manipulative lacked credibility, and attempts to dismiss Dafydd Iwan as representative of a small and misguided minority were disproved when a crowd of five thousand attended a protest against the investiture in Caernarfon-headed by a car, equipped with a loudspeaker, blaring "Carlo" as they processed through the streets. ${ }^{96}$ To dismiss these songs, as Dunaway might have put it, as "divid[ing] the world in an esoteric fashion, keeping out the faint-at-heart and including the devout" after the manner of left-wing American protest songs of the 1950s, ${ }^{97}$ would be to badly misread the mood among those opposed to the investiture.

In this way, we may better understand "Carlo," "Croeso Chwe Deg Nain," and the events of 1969 that surrounded them, pace Dafydd Iwan's own comments, as an exercise in counter-propaganda. At stake was the validity of the cultural renaissance then gripping the Welsh nation. It was not a simple case of pitting Welsh patriots against those Welsh people who were, in Dafydd Iwan's words, not "man enough" to "insist on their freedom" from English cultural imperialism. It is entirely possible to argue that the singer's detractors were just as concerned with the welfare of Welsh culture, but cleaved to a different conception of Welshness, one that emphasized unity with England and participation in the British cultural project; furthermore, this notion had its intellectual roots in deep-seated traditions that glossed the Welsh as the original Brythonic race-traditions that harkened back to the days of the (Welsh-descended) Tudor monarchs, and beyond. ${ }^{98}$ Nevertheless, Dafydd Iwan's pronouncements sought to frame the situation in terms of a rhetorical choice. Was Wales to continue in the same fashion as before, as a mere appendage of England, her citizens, ashamed of or apathetic towards a heritage they had been repeatedly informed was parochial and devoid of worth other than as a Celtic curio, happy to remain politically powerless, to allow

\footnotetext{
94 "Protest Songs: Those of the Top Forty and Those of the Streets," American Quarterly 22, no. 4 (1970): 814.

${ }^{95}$ Yr Herald Gymraeg a'r Genedl, February 24, 1969, 6, disingenuously asserts that many of those who bought the "Carlo" record were unaware of the messages of hate it contained. There are obvious parallels with the moral panics over 'subliminal messages' in heavy metal music. See Brian Longhurst, Popular Music and Society (Cambridge: Polity, 1995), 197, and references therein.

${ }^{96}$ Ellis, Investiture, 205.

${ }^{97}$ David King Dunaway, "Music and Politics in the United States," Folk Music Journal 5, no. 3 (1987): 288.

${ }^{98}$ See, for example, Dafydd Glyn Jones, The Secret of the Island of Britain (Cardiff: BBC, 1992).
} 
the English to "[elbow] our language / into the grave that we have dug for it," as poet R. S. Thomas had it, ${ }^{99}$ and possessed of a safely dormant (British) patriotism centered on love of the royal family, ready to be roused when the circumstances required it? Or would a different Wales emerge, one that possessed a measure of political autonomy (or even outright independence), in which the Welsh language flourished and the "servility" to the royal family Dafydd Iwan so detested would be forgotten? Or, as Ellis put it:

The [1911 and 1969] investitures ultimately hinged on questions of identity: what composed Welshness? Whom did the Welsh nation embrace and, by implication, who did it exclude? What was the character of the relationship between the Welsh nation and the British state? ${ }^{100}$

The investiture meant that this question could no longer be left in abeyance, and forging responses to it left permanent scars on the Welsh-language pop world. Dafydd Iwan's songs spawned imitators—such as the group of Cardiff students who won a prize at an inter-college eisteddfod in March for their song "Carlo, Watsha Mas" (Charles, Watch Out) ${ }^{101}$ —and supporters of the prince, such as the choir Parti Eryri ([Singing] Party of Snowdonia), who released an EP entitled Croeso $i$ Gaernarfon (Welcome to Caernarfon) that hovered around the lower reaches of the pop charts in the late spring. At least one pop group was split up by the diverging views of its members on the matter of performing at events attended by the prince during the celebrations, however; ${ }^{102}$ and a prominent Welsh-language pop magazine was forced to issue a retraction after printing an article satirizing the prince that mirrored the lyrics of "Carlo." ${ }^{103}$ Worst of all, the Welsh pop world's talisman found live bookings difficult to come by for some months afterward, as events organizers shunned him due to his anti-investiture stance. The banishment from the stage, however, could never be total or long-lasting-Dafydd Iwan's supporters were too numerous, and within ten years the erstwhile firebrand would not only be known for his singing exploits, but also as the successful co-founder of Wales's most prominent record label, presiding over a renaissance in Welsh-language popular music that could scarcely have been imagined as Prince Charles took his seat on the dais at Caernarfon.

\section{Diolchiadau/Acknowledgements}

The above was written as the result of a research trip to the British Film Institute in London funded by the Welsh-medium higher education institution, Coleg Cymraeg Cenedlaethol. The author would like to thank the Coleg for their generosity, as well as Hannah Curry and Steve Tollervey of the BFI, and Hannah Loy and Gwen James of BBC Cardiff for their assistance. Hoffwn ddiolch i Dafydd Iwan a Robat Gruffudd am eu cymorth, ac i'r ddau arfarnwr a benodwyd gan y cylchgrawn hwn, sef E. Wyn James a'r darllenydd arall sydd yn parhau yn anhysbys, am eu sylwadau defnyddiol ar ddrafft o'r erthygl hon. (I would also like to thank Dafydd Iwan and Robat Gruffudd for their support, and also the two referees appointed by this journal, E. Wyn James and another reader who remains anonymous, for their useful comments on a draft of this article.)

\footnotetext{
99 "Reservoirs," analyzed in W. Moelwyn Merchant, R. S. Thomas (Cardiff: University of Wales Press, 1979), 59-60. ${ }^{100}$ Ellis, Investiture, 319.

${ }^{101}$ Baner Ac Amserau Cymru, March 27, 1969, 3; Wyn, Be Bop a Lula'r Delyn Aur, 128-29, notes that these students were all members of the pop group Y Dyniadon Ynfyd Hirfelyn Tesog.

102 Sîn 4 (1973), 7.

${ }^{103}$ Asbri 2 (August 1969), 4.
} 


\section{References}

\section{Books/articles}

Davies, John. A History of Wales. London: Penguin, 1993.

Denisoff, R. Serge. "Protest Songs: Those of the Top Forty and Those of the Streets." American Quarterly 22, no. 4 (1970): 807-23. http://dx.doi.org/10.2307/2711871

Dunaway, David King. "Music and Politics in the United States." Folk Music Journal 5, no. 3 (1987): 26894.

Ellis, John S. Investiture: Royal Ceremony and National Identity in Wales, 1911-1969. Cardiff: University of Wales Press, 2008.

Griffiths, Peter Hughes. O Lwyfan i Lwyfan. Talybont: Y Lolfa, 2010.

Hill, Sarah. 'Blerwytirhwng?': The Place of Welsh Pop Music. Aldershot: Ashgate, 2007.

Iwan, Dafydd. Dafydd Iwan. Caernarfon: Gwasg Gwynedd, 1981.

Iwan, Dafydd. Holl Ganeuon Dafydd Iwan. Talybont: Y Lolfa, 1992.

Iwan, Dafydd. Cân dros Gymru. Caernarfon: Gwasg Gwynedd, 2002.

James, E. Wyn. "Painting the World Green: Dafydd Iwan and the Welsh Protest Ballad." Folk Music Journal 8 (2005): 594-618.

Johnes, Martin. "A Prince, a King, and a Referendum: Rugby, Politics, and Nationhood in Wales, 19691979." Journal of British Studies 47, no. 1 (October 2008): 129-48. http://dx.doi.org/10.1086/522347

—_. Wales since 1939. Manchester: Manchester University Press, 2012.

Longhurst, Brian. Popular Music and Society. Cambridge: Polity, 1995.

Merchant, W. Moelwyn. R. S. Thomas. Cardiff: University of Wales Press, 1979.

Morgan, Prys. "The Gwerin of Wales - Myth and Reality." In The Welsh and their Country, ed. I. Hume and W. T. R. Pryce, 134-52. Llandysul: Gomer, 1986.

Morris, Jan. The Princeship of Wales. Llandysul: Gomer, 1995.

Phillips, Dylan. Trwy ddulliau chwyldro . . ? : Hanes Cymdeithas yr Iaith Gymraeg 1962-1992. Llandysul: Gomer, 1998.

Thomas, R. S. Cymru or Wales? Llandysul: Gomer, 1992.

Wallis, Roger, and Krister Malm. "Sain Cymru: The Role of the Welsh Phonographic Industry in the Development of a Welsh Language Pop/Rock/Folk Scene.” Popular Music 3 (1984): 77-105. http://dx.doi.org/10.1017/S0261143000001574

Williams, Huw. Canu'r Bobol. Gwasg Gee: Dinbych, 1978.

Williams, Gwyn A. When Was Wales? London: Penguin, 1985.

Wyn, Hefin. Be Bop a Lula'r Delyn Aur: Hanes Canu Poblogaidd Cymraeg. Talybont: Y Lolfa, 2002.

\section{Conference papers}

Fowler, Carwyn. 'A Typology of Nationalism in Welsh rock/folk music', PSA Annual Conference, University of Leeds, 4th-7th April. 


\section{Newspapers/magazines}

Asbri

Baner ac Amserau Cymru

Caernarvon and Denbigh Herald

Carmarthen Times

$Y$ Clorianydd

Y Cymro

The Gazette/Y Clorianydd

Yr Herald Gymraeg a’r Genedl

Ŝरn 